\title{
CROWDFUNDING JAKO INNOWACYJNA METODA FINANSOWANIA PROJEKTÓW PRZEZ SPOŁECZEŃSTWO NA PRZYKŁADZIE BRANŻY FINTECH
}

\author{
Abstract \\ CROWDFUNDING AS AN INNOVATIVE WAY OF FINANCING PROJECTS BY \\ SOCIETY BASED ON THE FINTECH INDUSTRY
}

Lately, crowdfunding has emerged as an alternative source of raising needed money for different types of projects. This paper provides an overview of crowdfunding topic. It characterizes the main concept, shows its types as well as describes the benefits and risks that comes with raising money with the help of the people and Internet. The aim of the article is to show how crowdfunding can contribute to the growth of innovation in the country, especially based on the FinTech industry. The paper outlines the size of transactions value in the crowdfunding market and predicts reasonable growth for the next 5 years.

Key words: crowdfunding, regulations, FinTech, innovations, funds

\section{Wstęp}

W ostatnim czasie innowacje stały się kluczowym czynnikiem transformacji sektora finansowego. Wiele instytucji zaczyna traktować innowacyjność jako jedną z pierwszorzędnych metod, dzięki której są w stanie zbudować przewagę konkurencyjną. Zmiany technologiczne dają możliwość wykreowania nowych modeli biznesowych, poprawienia jakości świadczonych usług oraz powiększenia zasięgu działalności ${ }^{1}$. Szczególnie widoczne jest to na rynku usług finansowych - zmieniające

\footnotetext{
1 Zob. https://knf.gov.pl/dla_rynku/fin_tech (dostęp: 28.03.2019).
} 
się preferencje konsumentów oraz wzrastające oczekiwania powodują, że pośrednicy finansowi częściej wychodzą z inicjatywą nowych rozwiązań, tak aby sprostać oczekiwaniom klienta. Podejście do współczesnego zarządzania przedsiębiorstwem i dynamiczny rozwój gospodarki rynkowej zmieniają sposób postrzegania dotychczasowych metod zarządzania oraz zmuszają do nieustannego poszukiwania innowacyjnych rozwiązań. Dlatego też możemy mówić o gwałtownym rozwoju nowej branży finansowo-technologicznej określanej mianem FinTech. Zachodząca transformacja cyfrowa napędza proces zmian zarówno w otoczeniu regulacyjnym, jak i w sposobach finansowania przedsięwzięć. W większości główną rolę w tym przeobrażeniu odgrywa Internet, który tworzy społeczność zorientowaną na kreowanie nowych treści, projektów, zacieśnianie więzi czy finansowanie wyróżniających się pomysłów, jak dzieje się to w przypadku crowdfundingu.

Profesor Gregor Dorfleitner nazywa go jednym z segmentów branży FinTech, powstałym jako odpowiedź na trudności stawiane przed młodymi firmami podejmującymi próbę uzyskania środków finansowych w celu rozpoczęcia i rozwoju działalności. Crowdfunding umożliwia dostęp do finansowania zarówno dla osób prywatnych, jak i przedsiębiorstw ${ }^{2}$. Usytuowanie crowdfundingu w sektorze FinTech pozwala na lepsze zrozumienie istoty branży jako całości, jak i powiązania mechanizmu finansowania społecznościowego $\mathrm{z}$ innowacyjnymi usługami wykorzystującymi najnowsze technologie.

Przedmiotem badań w niniejszym artykule jest przedstawienie crowdfundin$g u$ jako innowacyjnej metody finansowania projektów przez społeczeństwo. Ogólna istota crowdfundingu została wsparta przedstawieniem obecnie występujących regulacji oraz ukazaniem wielkości i potencjału rynku ze zwróceniem uwagi na jego przewidywany w kolejnych latach wzrost. Analiza została wsparta statystykami z dwóch najbardziej popularnych platform crowdfundingowych w Polsce i na świecie, aby móc lepiej zobrazować wielkość zjawiska finansowania społecznościowego oraz jego wpływ na rozwój start-upów ze szczególnym uwzględnieniem branży FinTech.

\section{Crowdfunding jako innowacyjna metoda finansowania projektów przez społeczeństwo}

$\mathrm{Na}$ rynku od lat mamy do czynienia $\mathrm{z}$ alternatywnymi formami finansowania przedsiębiorstw oraz osób indywidualnych opierających się na kapitale społecznościowym. Jedną z tych metod jest crowdfunding, który powstał po kryzysie finansowym w 2008 roku jako odpowiedź na trudności stawiane przed młodymi firmami podejmującymi próby zebrania środków finansowych na rozpoczęcie swojej działalności. Kluczowy wpływ na popularyzację crowdfundingu miał rozwój Internetu

\footnotetext{
2 G. Dorfleitner, The FinTech Market in Germany, Regensburg 2016, s. 12-13.
} 
i social mediów, który umożliwił powstanie platform łączących przedsiębiorstwa poszukujące kapitału z potencjalnymi inwestorami, szczególnie tymi z niewielką wiedzą finansową i skłonnymi zapewnić również niewielkie wsparcie finansowe. Skumulowanie kilku małych kwot od różnych inwestorów jest jednak w stanie zagwarantować satysfakcjonującą wartość osobom poszukującym kapitału³.

Crowdfunding można zdefiniować jako gromadzenie środków finansowych uzyskanych od społeczeństwa na własne cele. To proces, do którego niezbędna jest większa liczba ludzi, decydujących się na przeznaczenie własnych środków pieniężnych na wsparcie wybranych projektów bądź pomysłów osób indywidualnych, przedsiębiorstw lub organizacji. Procedura ta pozwala na zgromadzenie i alokację niezbędnego kapitału potrzebnego do zrealizowania nowych przedsięwzięć, zazwyczaj w zamian za określone świadczenia zwrotne. Skupia się na świadczeniach pieniężnych od grupy pojedynczych jednostek zamiast profesjonalistów takich jak banki, anioły biznesu bądź fundusze wysokiego ryzyka. Cechą charakterystyczną crowdfundingu jest funkcjonowanie bez pośredników - komunikacja odbywa się za pośrednictwem Internetu i na platformach internetowych. Umożliwiają one wchodzenie $\mathrm{w}$ interakcje między osobą ubiegającą się o dofinansowanie a tak zwanym tłumem. Crowdfunding jest stosunkowo nowym zjawiskiem, znajdującym się na etapie nieustannego rozwoju, który może być definiowany w różny sposób. Zachowuje przy tym jednak zawsze stałe elementy:

- wsparcie ma charakter finansowy;

- zbiórki przeprowadzane są za pośrednictwem Internetu;

- osoby wspierające otrzymują tzw. świadczenia zwrotne - nagrody za wpłacone środki pieniężne;

- najczęściej przekazywane są relatywnie niskie kwoty;

- potencjalna liczba wspierających projekt jest nieograniczona;

- zbiórki mają charakter otwarty - każdy może przekazać datek z dowolnego miejsca i w wybranej wysokości oraz wie, kto zbiera pieniądze, na jaki cel i jakiej potrzebuje kwoty na jego realizację ${ }^{4}$.

W praktyce crowdfunding może zostać podzielony ze względu na stosowane modele, czyli to, w jaki sposób realizowany jest proces crowdfundingu. Ich cechą wspólną jest to, że w zbiórkach uczestniczy wcześniej wspomniana, nieograniczona liczba osób wspierających projekt, transakcje mogą dokonywać się bez pośredników, a uczestnicy mogą być rozporoszeni geograficznie. W każdym modelu znajdują się: inicjator zbiórki, którym może być zarówno osoba fizyczna, jak i organizacja; kapitałodawca - w zależności od modelu jest to inwestor, pożyczkodawca bądź donator; platforma crowdfundingowa, czyli medium znajdujące się pomiędzy inicjatorem projektu a osobami wspierającymi. Platformy ułatwiają dotarcie do dużej

${ }^{3}$ F. Hervé, A. Schwienbacher, Crowdfunding and Innovation, „Journal of Economic Surveys" 2018, t. 32, nr 5, s. 7.

${ }^{4} \mathrm{~J}$. Ziobrowska, Crowdfunding jako nowoczesna forma wsparcia przedsięwzięć społecznych, kulturowych i biznesowych, „Finanse, Rynki Finansowe, Ubezpieczenia” 2016, nr 3 (81), s. 285-295. 
grupy odbiorców z możliwością prezentacji oraz kontroli przedsięwzięcia, zapewniają system płatności i nadzorują procesy nagradzania ${ }^{5}$.

W zależności od tego, jak przedstawia się relacja pomiędzy osobami wspierającymi projekt a twórcą, można wyróżnić cztery główne typy crowdfundingu:

1) model donacyjny - do którego zalicza się model bez nagradzania osób wspierających oraz model wykorzystujący nagradzanie uczestników, zwany dalej sponsorskim;

2) model pożyczkowy - wyróżniający model pożyczek społecznych oraz model mikropożyczek;

3) model inwestycyjny;

4) modele mieszane6.

Tylko w jednym przypadku relacja ta nie jest dwustronna. Jest to najpopularniejszy model crowdfundingu nazywany modelem donacyjnym, niewykorzystującym nagradzania uczestników. Zakłada on dokonywanie wpłat przez osoby finansujące na określony cel, przy założeniu, że nie jest to powiązane z żadnym świadczeniem zwrotnym. Ma on charakter filantropijny i nie przewiduje żadnych form gratyfikacji poza ewentualnym podziękowaniem - beneficjent nie jest więc zobowiązany do wzajemnego świadczenia wobec osób finansujących przedsięwzięcie. Projekty w tym modelu są najczęściej inicjatywami społecznymi nierealizowanymi dla zysku, lecz powiązanymi z działaniami charytatywnymi, badaniami itp. Odmianą modelu donacyjnego jest również model opierający się na nagradzaniu uczestników finansujących przedsięwzięcie. Otrzymują oni określony rodzaj wynagrodzenia nazywany świadczeniem wzajemnym za dokonanie wpłaty określonych środków pieniężnych. Bardzo często jest to nagroda niefinansowa, przekazywana w dalszym etapie w zamian za ich wkład w rozwój projektu lub pomysłu. Ten model zwykle koncentruje się na wspieraniu kreatywnych projektów i jednostek, gdzie w zamian za wkład własny finansujący otrzymują nagrody rzeczowe, na przykład w postaci płyt zespołów bądź biletów na koncerty. Nie występuje tu zatem ekonomiczna ekwiwalentność świadczeń obu stron, ponieważ finansujący otrzymuje przeważnie świadczenie o mniejszej wartości. Mniej popularnym, lecz nadal wykorzystywanym modelem jest model pożyczkowy, który umożliwia bezpośrednie pożyczanie środków pieniężnych pomiędzy podmiotami bez pośrednictwa tradycyjnych instytucji finansowych, na przykład banków. Jest alternatywą dla tradycyjnych pożyczek z mniej restrykcyjnymi procedurami otrzymania ich. Kolejnym wyróżnionym modelem jest crowdfunding inwestycyjny, zwany inaczej udziałowym. W przypadku opcji udziałowej świadczenie zwrotne przybiera postać udziałów, akcji bądź innych instrumentów finansowych. Oznacza to, że w zamian za dokonanie wpłaty uczestnicy stają się faktycznymi współwłaścicielami spółki, która zdecydowała się na zebranie kapitału w ten sposób. Aby emisja akcji była możliwa,

${ }_{5}$ A. Szopa, Charakterystyka modeli i platform crowdfundingowych w Polsce, [w:] A. Pluszyńska, A. Szopa (red.), Crowdfunding w Polsce, Wydawnictwo Uniwersytetu Jagiellońskiego, Kraków 2018, s. 34.

6 Tamże, s. 36. 
projektodawca powinien działać $\mathrm{w}$ formie spółki komandytowo-akcyjnej lub akcyjnej. Najczęściej wykorzystywany jest przez młode firmy dopiero co wchodzące na rynek albo będące we wczesnej fazie rozwoju. Ostatni przedstawiony model, czyli model mieszany bądź hybrydowy, stanowi dowolne połączenie wszystkich wyżej wymienionych modeli - daje możliwość uczestnictwa we wszystkich modelach lub dopuszcza dokonanie wybranej kombinacji (w tym przypadku mamy do czynienia $\mathrm{z}$ modelem niepełnym $)^{7}$.

Istotne jest również zwrócenie uwagi na korelację pomiędzy crowdfundingiem a innowacjami oraz to, w jaki sposób może on stymulować ich rozwój. Finansowanie społecznościowe zapewnia niezbędny kapitał projektom, które mogłyby zostać niezrealizowane bądź zrealizowane, lecz w sposób mniej efektywny. Projekty zwieńczone sukcesem gwarantują im dalszy rozwój i zainteresowanie klientów, ponieważ potencjalni inwestorzy są równocześnie późniejszymi konsumentami, mogą oni też dać natychmiastowy feedback na temat produktu. Pogląd ten jest zgodny z modelem rozwiniętym przez Strausza (2017), który podkreślał, że crowdfunding nie jest skutecznym sposobem na złagodzenie problemu pokusy nadużyć, jak dzieje się to w przypadku banków bądź venture capital. Sukces finansowania społecznościowego w tym wypadku pochodzi ze zdolności do zmniejszania niepewności co do zagregowanego popytu ${ }^{8}$.

\section{Analiza rynku crowdfundingu}

Platformy crowdfundingowe zachowują się jak uczestnicy rynkowi pośredniczący między beneficjentami a osobami finansującymi dane przedsięwzięcie. Oferują niezbędną infrastrukturę internetową i przestrzeń do prezentacji. Pod koniec 2018 roku na świecie działało ponad 2000 platform crowdfundingowych. Największe i najpopularniejsze z nich - Kickstarter i Indiegogo, które są dostępne dla obywateli prawie każdego państwa, posiadają elastyczne modele kategorii kampanii oraz swobodę zarządzania jej przebiegiem. Według statystyk publikowanych na stronie Kickstartera dzięki platformie udało się pomyślnie sfinansować 162616 projektów, co $\mathrm{w}$ ujęciu procentowym wynosi $37 \%$ wszystkich projektów, w tym ponad 300 $\mathrm{z}$ nich uzyskało dofinansowanie w kwocie 1 miliona dolarów9

Kampania, która osiągnęła do tej pory najwyższe wsparcie w historii Kickstartera, potwierdza założenie, że dzięki crowdfundingowi można uzyskać kluczowe kwoty niezbędne do rozwoju działalności oraz to, iż dobrze prowadzone kampanie marketingowe docierające do zainteresowanego konsumenta są w stanie

${ }^{7}$ K. Król, Crowdfunding. Od pomystu do biznesu, dzięki społeczności, Crowdfunding.pl, Warszawa 2013, s. 57-60.

${ }^{8}$ F. Hervé, A. Schwienbacher, Crowdfunding..., dz. cyt., s. 6.

9 Zob. https://kickstarter.com/help/stats (dostęp: 4.05.2019). 
zagwarantować sukces i rozpoznawalność marki. Przykładem odniesionego sukcesu jest prowadzona kampania Pebble Time - start-upu zajmującego się smartwatchami, który zebrał ponad 20 milionów dolarów i został wsparty przez ponad 78 tysięcy osób. Celem kampanii było uzyskanie 500 tysięcy dolarów, wypracowana suma przekroczyła więc ponad 40 razy zamierzony plan. Wskazuje to również na fakt zainteresowania obecnego konsumenta nową technologią usprawniającą życie codzienne, co łączy się z jednoczesnym ułatwieniem firmom FinTech poszukiwania kapitału na platformach crowdfundingowych.

Rysunek 1. Wynik kampanii Pebble Time prowadzonej na platformie Kickstarter

\section{Pebble Time - Awesome Smartwatch, No \\ Compromises}

\section{Project We Love P Palo Alto,CA - Product Design}

\section{$\$ 20,338,986$}

pledged of $\$ 500,000$ goal

\section{8,471}

backers

Źródło: https://www.kickstarter.com/projects/getpebble/pebble-time-awesome-smartwatch-no-compromises (dostęp: 6.06.2019).

Równie obiecująco kształtuje się cały rynek crowdfundingu. Według danych przedstawionych przez portal Statista.com wartość transakcji w segmencie finansowania społecznościowego wynosi w 2019 roku 6,13 miliarda euro, a dokonane szacunki ukazują, że wartość całkowitych transakcji w perspektywie pięciu lat wzrośnie do 10,61 miliarda euro. Mimo że z każdym okresem proporcjonalny wzrost rynku maleje, dynamika wzrostu zawsze zachowuje wartość dodatnią, co wpływa na systematyczne powiększanie się rynku crowdfundingu.

Mimo iż to w Stanach Zjednoczonych crowdfunding cieszy się największą popularnością oraz osiąga najlepsze wyniki, również w Polsce można zauważyć postępującą tendencję wzrostu tego typu źródła finansowania alternatywnego. Dużą popularnością cieszą się uniwersalne platformy, czyli polskie odpowiedniki amerykańskich platform - Wspieram.to oraz Polakpotrafi.pl, które wykorzystują crowdfunding w modelu opartym na nagrodach. Obie platformy oferują wiele różnorodnych opcji i kategorii, opierając się na pobieranych prowizjach wyłącznie od zrealizowanych projektów, w głównej mierze przy wykorzystaniu tak zwanego modelu „wszystko albo nic”. Jest to strategia nagradzania, która oznacza, że inicjator otrzyma środki finansowe jedynie w przypadku zgromadzenia całej zadeklarowanej w projekcie kwoty. Jeśli zgromadzona kwota będzie poniżej założonego progu, wówczas następuje automatyczny zwrot pieniędzy dla wszystkich osób, które wsparły projekt. Obie platformy mają podobny zasięg oraz liczbę wspierających czy sumę zebranych pieniędzy. Ponadto platforma Wspieram.to udostępnia na bieżąco swoje wyniki, które na początku maja bieżącego roku kształtują się następująco: 
Diagram 1. Szacowany wzrost wartości rynku crowdfundingu (mld EUR).

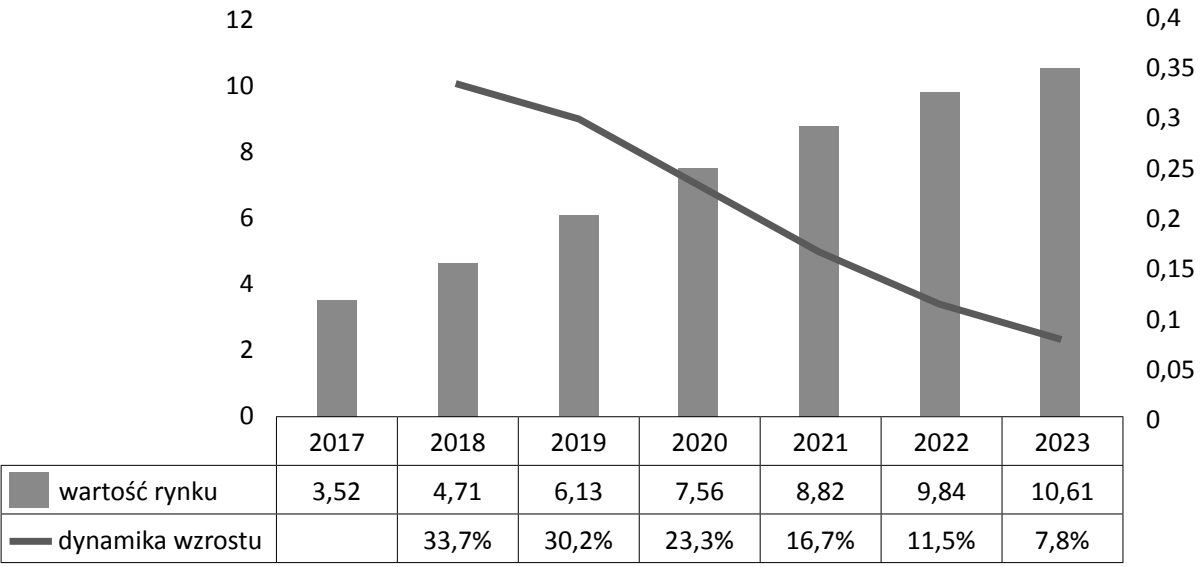

Źródło: opracowanie własne na podstawie danych zamieszczonych na platformie https://www.statista. com/outlook/335/100/crowdfunding/worldwide (dostęp: 24.06.2019).

- łączna suma wpłaconych środków - 22988109 zł;

- średnia wielkość wpłaty - 78,88 zł;

- średnia liczba osób wspierających udaną kampanię - 135,73;

- największa liczba osób wspierających jedną kampanię - 8138;

- największa udana kampania - $854675 \mathrm{zf}^{10}$.

Przedstawione wyżej statystyki wskazują na duże zainteresowanie tą formą alternatywnego źródła finansowania - zwłaszcza biorąc pod uwagę fakt, iż platforma funkcjonuje od sześciu lat i jest jedną z wielu w całym kraju. Na rosnącą popularność crowdfundingu może wskazywać łatwa dostępność dla przedsięwzięć w bardzo wczesnych fazach rozwoju oraz obniżone bariery wejścia, co przeciwdziała wykluczeniu finansowemu. Niezbędny kapitał mogą uzyskać tu w szczególności małe i średnie przedsiębiorstwa, które w banku nie byłyby w stanie wykazać wystarczającej zdolności kredytowej wymaganej na zaciągnięcie kredytu bankowego. Występuje tu także znaczna dywersyfikacja portfela inwestycji i rozproszenie ryzyka ze względu na występowanie dużej liczby inwestorów, która $z$ kolei przekłada się na zwiększone szanse odniesienia sukcesu wytypowanych spółek. Ograniczony zostaje tu również wpływ czynnika położenia geograficznego siedziby beneficjenta. Dawcy kapitału z natury preferują spółki, które znajdują się w ich bliskim otoczeniu - zależność tę można zauważyć w przypadku aniołów biznesu, którzy częściej angażują się w Polsce w spółki znajdujące się w ich rejonie. Gdy rynek transferu kapitału

10 Zob. https://wspieram.to/dlaczego_my (dostęp: 4.05.2019). 
zostaje przeniesiony do Internetu, powoduje to, że te same inwestycje są dostępne dla większej liczby potencjalnych inwestorów ${ }^{11}$.

Długa lista korzyści finansowych oraz zrealizowanych projektów może sprawiać mylne wrażenie, że jest to mechanizm niemal wolny od wad. Jednak jak każdy rodzaj próby uzyskania źródła finansowania posiada on zarówno wady, jak i ryzyka. Próba pozyskania kapitału wymaga przekonania do swojego pomysłu dużej liczby osób jednocześnie. Świadczą o tym statystyki przedstawione na platformie Wspieram.to, gdzie średnio jedna osoba jest w stanie przeznaczyć na nowy projekt 80 złotych. Każdy realizowany pomysł ma ograniczony okres życia na stronie, który przeznaczony jest na zebranie zadeklarowanej kwoty. Osoba ubiegająca się o fundusze nie ma również pewności, czy jej pomysł zostanie przyjęty przez społeczność i czy będzie ona skłonna zainwestować w przedstawiony projekt. Wynikiem tego może być strata pieniędzy przeznaczonych na wcześniejszą kampanię promocyjną, a także narażenie projektu na odsłonięcie go przed konkurencją $\mathrm{z}$ tej samej branży ${ }^{12}$.

\section{Regulacje oraz obecne zastosowanie przepisów prawa w obszarze crowdfundingu}

Istotnym punktem rozwoju crowdfundingu w Polsce jest również opublikowanie raportu przez Zespół roboczy ds. rozwoju innowacji finansowych (FinTech), powołany z inicjatywy Urzędu Komisji Nadzoru Finansowego. Raport powstał w związku z wątpliwościami pojawiającymi się w przypadku interpretacji przepisów dotyczących stosowania crowdfundingu oraz powiązanych $\mathrm{z}$ nimi przepisów prawa $\mathrm{w}$ obszarze rynku finansowego. Dokument sporządzono w celu zwiększenia pewności prawnej oraz popularyzacji crowdfundingu pośród uczestników rynku. Przeprowadzone analizy ukazały, że skala fraudów w większości modeli crowdfundingowych jest marginalna i na obecnym etapie nie jest wymagane podejmowanie działań regulacyjnych. W tym wypadku fraudy rozumiane są jako działania, które mają na celu wprowadzenie w błąd zarówno odbiorców, jak i samą platformę. Jedyna rekomendacja Zespołu wystąpiła w przypadku crowdfundingu inwestycyjnego i dotyczyła uproszczenia trybu składania ofert publicznych do 1 miliona euro. W tym modelu można stosować ustawę o ofercie publicznej, jednak obecne przepisy pozwalają na przeprowadzenie publicznej emisji papierów wartościowych do wysokości 100 tysięcy euro w ciągu roku, bez obowiązku sporządzania prospektu emisyjnego. Dlatego też w trakcie prac Zespołu wysunięto wstępną propozycję, która miałaby uprościć tryb składania ofert do kwoty 1 miliona euro ${ }^{13}$. Sporządzenie ni-

${ }^{11}$ K. Król, Crowdfunding..., dz. cyt., s. 80.

12 Tamże, s. 55.

${ }^{13}$ Raport z prac Zespołu roboczego ds. rozwoju innowacji finansowych, KNF, Warszawa 2017, s. 130. 
niejszego dokumentu przez Zespół roboczy ukazał, iż na obecnym etapie rozwoju crowdfunding $u$ w Polsce nie jest potrzebne tworzenie odrębnych regulacji, ale każdy model warto rozpatrywać indywidualnie, mając na uwadze obowiązujące przepisy prawa. Mimo to istotne jest zastanowienie się nad wprowadzeniem nadzoru nad działalnością platform crowdfundingowych. Rynek ten w Polsce jest nadal na wczesnym etapie rozwoju, lecz bardzo istotne jest uniknięcie przeregulowania i narzucenia na platformy zbyt obciążających warunków i obowiązków w przyszłości. Dlatego interesującym rozwiązaniem jest wprowadzenie modelu zrównoważonego nadzoru, który zakładałby obowiązek rejestracji działalności platform w organie sprawującym nadzór. Rejestracja ta powinna ograniczać się jednak do wypełnienia prostego formularza zgłoszeniowego i umożliwić platformie rozpoczęcie działalności w ciągu siedmiu dni od zgłoszenia. Wszystkie ewentualne obowiązki sprawozdawcze powinny być dostępne online i ograniczać się do przekazywania podstawowych informacji oraz nie powinny być powielane w stosunku do już istniejących. W przypadku crowdfundingu udziałowego warto zachęcać inwestorów zawodowych do inwestowania razem $\mathrm{z}$ inwestorami indywidualnymi. Dla inwestorów indywidualnych natomiast należy rozważyć wprowadzenie zachęt podatkowych oraz umożliwić dalszy obrót nabytymi jednostkami. Prowadzenie działalności przez platformy crowdfundingowe powinno podlegać regulacji, jednak nie tak restrykcyjnej jak przepisy dotyczące firm inwestycyjnych. Wyżej wymienione podstawy regulacyjne mają na celu skupienie się na rozwoju finansowania społecznościowego poprzez ułatwienie prowadzenia go w Polsce $^{14}$.

\section{Podsumowanie}

Pomimo umiarkowanego i ciągłego rozwoju crowdfunding w porównaniu z innymi krajami nie jest w Polsce zjawiskiem powszechnym. Choć nadal dominujący jest model donacyjny, powoli coraz większego wpływu zaczynają nabierać także platformy działające w modelach inwestycyjnym i pożyczkowym. Zjawisko to jednak zachodzi szczególnie w krajach, w których crowdfunding jest szeroko rozpowszechniony. Zakłada się również, że modele finansowania społecznościowego będą ewoluowały stopniowo i tworzyły nowe możliwości dla osób poszukujących kapitału, jak i dla wspierających projekty. Wsparcia w tym sposobie finansowania przedsięwzięć mogą poszukiwać zwłaszcza firmy z sektora nowych technologii, ponieważ znajdują się one obecnie w gronie zainteresowania konsumentów, którzy jednocześnie są potencjalnymi inwestorami na platformach crowdfundingowych. $\mathrm{Na}$ rozwój crowdfundingu w Polsce wpływ będzie miało też zjawisko współpracy pomiędzy platformami a innymi podmiotami obecnymi na rynku. Przykładem tego

${ }^{14}$ W. Szpringer, Nowe technologie a sektor finansowy. FinTech jako szansa i zagrożenie, Wydawnictwo Poltext, Warszawa 2017, s. 114-118. 
jest porozumienie podpisane między platformą Beesfund a Giełdą Papierów Wartościowych SA, które ma na celu stworzenie wspólnej platformy promującej start- upy z Polski. Takie zależności będą z pewnością wspierać procesy finansowania oraz mieć wpływ na rozwój innowacyjności i przedsiębiorczości w kraju, a także na wzrost zainteresowania tym zjawiskiem w Polsce ${ }^{15}$.

\section{Bibliografia}

Dorfleitner G., The FinTech Market in Germany, Regensburg 2016.

Hervé F., Schwienbacher A., Crowdfunding and Innovation, „Journal of Economic Surveys" 2018, t. 32, nr 5.

Król K., Crowdfunding. Od pomystu do biznesu, dzięki społeczności, Crowdfunding.pl, Warszawa 2013.

Raport z prac Zespołu roboczego ds. rozwoju innowacji finansowych, KNF, Warszawa 2017.

Strausz R., A Theory of Crowdfunding: A Mechanism Design Approach with Demand Uncertainly and Moral Hazard, Discussion Paper no. 2, Germany 2017.

Szopa A., Charakterystyka modeli i platform crowdfundingowych w Polsce, [w:] A. Pluszyńska, A. Szopa (red.), Crowdfunding w Polsce, Wydawnictwo Uniwersytetu Jagiellońskiego, Kraków 2018

Szpringer W., Nowe technologie a sektor finansowy. FinTech jako szansa i zagrożenie, Wydawnictwo Poltext, Warszawa 2017.

Ziobrowska J., Crowdfunding jako nowoczesna forma wsparcia przedsięwzięć społecznych, kulturowych i biznesowych, „Finanse, Rynki Finansowe, Ubezpieczenia” 2018, nr 3 (81), s. 285-295.

Źródła internetowe:

https://knf.gov.pl/dla_rynku/fin_tech (dostęp: 28.03.2019)

https://wspieram.to/dlaczego_my (dostęp: 4.05.2019)

https://kickstarter.com/help/stats (dostęp: 4.05.2019)

${ }^{15}$ A. Szopa, Charakterystyka..., dz. cyt., s. 44. 